\title{
Inflammation Inhibits Muscarinic Signaling in In Vivo Canine Colonic Circular Smooth Muscle Cells
}

\author{
SUDARSHAN RAO JADCHERLA \\ Sections of Neonatology, Pediatric Gastroenterology and Nutrition, Department of Pediatrics, Medical \\ College of Wisconsin, Milwaukee, Wisconsin, U.S.A.
}

\begin{abstract}
We investigated the effects of experimental colitis on the muscarinic signaling properties and contractile behavior of canine colonic circular smooth muscle. The hypotheses that inflammation 1) inhibits in vivo muscarinic receptor mediated contractions, and 2) alters receptor density or receptor-binding affinities were tested. Muscarine was infused close-intra-arterially in seven conscious dogs during normal and experimental colitis states. Colonic circular muscle contractions were recorded via surgically attached strain gauge transducers. Muscarine stimulated phasic contractions in a dose-dependent manner, whereas colitis was inhibited. The inhibitory concentration $50 \%$ dose of $\mathrm{M}_{3}$ receptor inhibitor was several times lower than that of $M_{1}, M_{2}$, and $\mathrm{M}_{4}$ inhibitors during normal and colitis. However, inflammation induced a significant leftward shift in the circular muscle inhibitory dose-response curve of $\mathrm{M}_{2}$ inhibitor. Muscarinic receptor density and binding analyses in isolated circular muscle cells was done in normal and colitis states. Inflammation significantly decreased maximum binding from $4082 \mathrm{fmol} / \mathrm{mg}$ to 2708 $\mathrm{fmol} / \mathrm{mg}$, whereas affinity constant remained unaffected. The conclusions were that 1) spontaneous and muscarine-activated in vivo phasic contractile activity of colonic circular muscle cells is primarily mediated by $\mathrm{M}_{3}$ receptors; 2) inflammation was associated with a shift in $\mathrm{M}_{2}$ receptor potency, due chiefly to a decrease in receptor density; and 3) this inhibitory effect was
\end{abstract}

\section{ABSTRACT}

seen in normal and inflamed states, suggesting the importance of $\mathrm{M}_{2}$ receptor. These findings suggest that changes in muscarinic response during colitis may contribute to the abnormal motility seen with inflammatory bowel disease. (Pediatr Res 52: 756$762,2002)$

Ach, acetylcholine

\section{Abbreviations}

AUC, area under contractions

4-DAMP, 4-diphenyl acetoxy- $N$-methyl-piperidine methiodide

Methoctramine, N, N',-bis[6[[(2-methoxyphenyl)

methyl]amino]hexyl]-1,8-octanediamine tetrahydrochloride

TTX, tetrodotoxin

$\mathbf{I P}_{\mathbf{3}}$, inositol $(1,4,5$,)-triphosphate

DAG, diacylglycerol

PKC, protein kinase $\mathrm{C}$

IC $_{\mathbf{5 0}}$, inhibitory concentration $50 \%$

$\mathbf{E C}_{\mathbf{5 0}}$, excitatory concentration $50 \%$

$\mathbf{B}_{\text {max }}$, binding maximum

$\mathbf{K}_{\mathbf{d}}$, affinity constant

SMC, smooth muscle cells

$\left[{ }^{3} \mathbf{H}\right] \mathbf{Q N B}, 1$-quinuclidinyl[phenyl-4- $\left.{ }^{3} \mathrm{H}\right]$ benzilate

MPO, myeloperoxidase

Arterial, close-intra-arterial
$\mathrm{ACh}$, the principal neurotransmitter of the enteric nervous system, is released not only as a result of parasympathetic activation, but also in response to many other gastrointestinal peptides (1). Atropine (nonselective muscarinic antagonist), when administered intravenously or close-intra-arterially (arterial) completely blocks all spontaneous smooth muscle con-

Received July 24, 2001; accepted May 31, 2002.

Correspondence: Sudarshan R. Jadcherla, M.D., F.R.C.P.I., D.C.H., Associate Professor, Section of Neonatology, Department of Pediatrics, Childrens' Hospital Columbus, The Ohio State University, 700 Childrens' Drive, Columbus, OH 43205; e-mail: jadcherlas@pediatrics.ohio-state.edu

Support by the Children's Hospital of Wisconsin Foundation and Medical College of Wisconsin, Milwaukee, WI, and National Institutes of Health (National Institute of Diabetes and Digestive and Kidney Diseases) Grant 1 RO3 61502.

DOI: 10.1203/01.PDR.0000032074.08665.D0 tractions in the gut (1-3). In the gastrointestinal system, muscarinic receptors play a significant role in coordination of peristalsis and propulsion of luminal contents (4).

The muscarinic receptors in the gut are localized at presynaptic, postsynaptic, and prejunctional and postjunctional sites (5). These receptors on smooth muscle cells mediate contractions by G-protein coupled mechanisms, whereas those at presynaptic and prejunctional sites modulate the release of ACh by negative feedback. The activation of muscarinic receptors at postsynaptic sites stimulates postsynaptic excitatory and inhibitory neurons to release neurotransmitters. The physiologic mechanisms by which muscarinic receptors stimulate in vivo colonic circular muscle contractions are not completely understood. 
In the human colon, ulcerative colitis inhibits phasic contractions and increases giant migrating contractions, and similar findings are noted in canine colon (6-9). The inhibitory effect of colonic inflammation on spontaneous phasic contractions has been observed in earlier studies $(9-11)$. In vitro, at the myenteric plexus level at least in rats, excitatory neuronal function may be inhibited, resulting in a decrease in the release of ACh (12), whereas at the circular muscle cell, there may be a decrease in the density or affinity of muscarinic receptors (13).

This study aimed to 1) identify the muscarinic receptor subtypes that mediate the in vivo colonic circular muscle contractions during normal and inflamed states; and 2) determine the effect of colonic inflammation on muscarinestimulated contractile activity. Specifically, the hypothesis that inflammation inhibits muscarinic receptor-mediated contractions in vivo, and that inflammation alters receptor density and/or receptor-binding affinities was tested.

\section{METHODS}

Animal care approval. This project was approved by the Animal Care Committees at the Zablocki Veterans Affairs Medical Center and the Medical College of Wisconsin, Milwaukee. The National Institutes of Health guidelines on animal care safety have been adhered to. A minimum number of animals were used to achieve a statistically valid study.

Reagents and chemicals. The following substances were used: atropine sulfate (Eli Lilly, Indianapolis, IN, U.S.A.); hexamethonium chloride (ICN Pharmaceuticals, Cleveland, OH, U.S.A.); pirenzepine dihydrochloride, methoctramine tetrahydrochloride, and 4-DAMP (Research Biochemical International, Natick, MA, U.S.A.); and muscarine chloride, tropicamide, and TTX (Sigma Chemical, St. Louis, MO, U.S.A.). All substances were dissolved in $0.9 \% \mathrm{NaCl}$ and kept frozen at $-20^{\circ} \mathrm{C}$ when not used. Polyethylene glycol 3350 electrolyte mixture (Colyte, Reed and Carnick, Piscataway, NJ, U.S.A.) was used to cleanse the colon before inducing inflammation.

Collagenase type II (319U/mg, Worthington Biochemicals, Freehold, NJ, U.S.A.), soybean trypsin inhibitor (Worthington Biochemicals), and amino acid supplement (B.M.E. amino acid supplement, M.A. Bioproducts, Walkersville, MD, U.S.A.) were used for smooth muscle cell dispersion techniques. ${ }^{3}[\mathrm{H}] \mathrm{QNB}$ (Du Pont NEN, Boston, MA, U.S.A.) was used for muscarinic receptor binding studies.

Surgical procedures. Surgical procedures were done as described previously with some modifications (14). Briefly, seven mixed breed dogs of either sex (weight range 18-24 kg, $21.3 \pm 0.8 \mathrm{~kg})$ were anesthetized with i.v. sodium pentobarbital $(30 \mathrm{mg} / \mathrm{kg})$, and mid-ventral laparotomy was performed. The branches of ileocolic and middle colic arteries were identified in the proximal and distal colon, respectively. One branch artery in each region was carefully dissected from the mesentery while preserving the attached neurons. A silastic catheter (ID $0.75 \mathrm{~mm}$; OD $1.63 \mathrm{~mm}$; Corning, Corning, NY, U.S.A.) was inserted and secured so that its tip rested 1-2 mm from the junction of the branch artery and the main artery. The boundaries of each infused segment measured approximately 5-6 $\mathrm{cm}$. One electrode-strain gauge pair and two strain gauge transducers were attached to the seromuscular layer parallel to the circular muscle axis in each infused segment by $3-0$ Surgilon sutures, to record circular muscle contractions. Two additional strain gauge transducers were then attached, one between the proximal and the distal infused segment, and one caudal to the distal infused segment. The lead wires of the transducers were exteriorized through an Amphenol plug embedded in a stainless steel cannula (14).

An intraluminal silastic catheter (ID $2.6 \mathrm{~mm}$, OD $4.9 \mathrm{~mm}$; Corning) was implanted into the colon, $5 \mathrm{~cm}$ distal to the ileocolonic junction. All catheters were exteriorized subcutaneously in the subscapular region and were housed safely within jackets. The arterial catheters were flushed twice daily with $2000 \mathrm{IU}$ of heparin. The animals were allowed $7 \mathrm{~d}$ to recover from surgery before study.

\section{Protocol for in vivo measurements}

Experiments were done, first in the normal colon and then in the inflamed colon, with each animal serving as its own control. Contractile activity was recorded for about $1 \mathrm{~h}$ to identify the quiescent and contractile states. Contractile and electrical signals were recorded on a 12-channel pen recorder (model 7D; Grass Instrument Co., Quincy, MA, U.S.A.) with lower and upper cut-off frequencies set at direct current and 15 $\mathrm{Hz}$, respectively.

All substances were diluted with $0.9 \%$ saline and infused at $1 \mathrm{~mL} / \mathrm{min}$ arterially for $1 \mathrm{~min}$. After each infusion, catheters were flushed with $0.9 \%$ saline $(1 \mathrm{~mL})$, infused over $1 \mathrm{~min}$. All agonists were infused during a quiescent period. Catheter patency was confirmed daily, by the response of the segmental contractile activity after muscarine infusion $(5 \mathrm{nmol} / \mathrm{mL} / \mathrm{min}$ for $1 \mathrm{~min}$ ). Successive infusions (dose range of $0.1-20 \mathrm{nmol}$ ) were separated by intervals of at least $30-40 \mathrm{~min}$ to avoid tachyphylaxis and residual effects. Preliminary experiments established that contractile responses to repeated infusions of muscarine did not vary over time.

TTX (75 nmol) was infused to block sodium channel activity in enteric neurons. Hexamethonium $(70 \mu \mathrm{mol})$ was infused to inhibit nicotinic receptors in the enteric ganglia. In some experiments, antagonists to muscarinic receptors were infused $1 \mathrm{~min}$ before infusion of muscarine. The relatively selective blockers pirenzepine against $\mathrm{M}_{1}$ receptors (15-17), methoctramine against $\mathrm{M}_{2}$ receptors $(15,17)$, 4-DAMP against $\mathrm{M}_{3}$ receptors $(5,16)$, tropicamide against $\mathrm{M}_{4}$ receptors $(16,17)$, and atropine (nonselective) were used.

Electrical field stimulation (EFS) was applied via the electrodes at $10 \mathrm{~V}, 10 \mathrm{~Hz}$, at $1 \mathrm{~ms}$ pulse duration for $1 \mathrm{~min}$ to test intact nerve-muscle interaction.

Induction of colonic inflammation. After control experiments were completed, colonic inflammation was induced by mucosal exposure to ethanol and acetic acid, as previously described $(9,14,18,19)$. Briefly, the intraluminal catheter was irrigated with $500 \mathrm{~mL}$ of PEG 3350 electrolyte mixture to clear the luminal contents. After sedation with tiletamine and zolazepam (each $10 \mathrm{mg} / \mathrm{kg}$ ), 95\% ethanol was infused via the intraluminal catheter $(75 \mathrm{~mL}$ at $5 \mathrm{~mL} / \mathrm{min})$, and into the rectum 
(40 $\mathrm{mL}$ via a silastic tube with its tip $15 \mathrm{~cm}$ from the anal margin); $10 \mathrm{~min}$ later, $10 \mathrm{~mL}$ and $5 \mathrm{~mL}$ of $75 \%$ acetic acid was infused via the intraluminal catheter and rectal route respectively, and $5 \mathrm{~min}$ later, the colon was irrigated with $100 \mathrm{~mL}$ of $0.9 \%$ saline through the intraluminal catheter. Experiments were begun the following day.

Myeloperoxidase assay. MPO $(20,21)$ and protein assays (22) were performed, as per the methods described before, on tissues obtained from normal and inflamed colon. The method of tissue collection and assay are briefly stated below. The tissues were washed thoroughly with ice-cold $0.9 \%$ saline, and debris and fat removed. Using sharp dissection, the tissue was separated into mucosa-submucosal fraction and circular muscle fraction. Each fraction was weighed and a known volume (20 times the tissue weight) of homogenizing buffer was added to the tissue fraction, and then homogenized in ground-glass homogenizing tubes with ground-glass pestles. The homogenized tissue was stored, frozen in liquid nitrogen, and then thawed. This freeze-thaw cycle was repeated three times and stored at $-60^{\circ} \mathrm{C}$ until assay. Just before the assay, the tissue homogenate was centrifuged for $10 \mathrm{~min}$ at $2000 \mathrm{rpm}$, and the supernatant drawn off. The assay for MPO activity and protein assay in the supernatant was done as described (20-22).

Smooth muscle cell isolation. Smooth muscle cells were isolated according to the methods described before (23-25). Briefly, colon tissue was thoroughly washed in ice-cold $0.9 \%$ saline to clear the debris, and then placed in ice-cold oxygenated $N$-2-hydroxyethylpiperazine- $N$-2-ethane-sulphonic acid (HEPES) buffer on ice. Using a sharp dissection technique, the longitudinal muscle layer was first peeled off, and next the circular muscle layer was saved. Tissue squares $(5 \mathrm{~mm} \times 5$ $\mathrm{mm}$ ) from the circular muscle were treated with $0.05 \%$ collagenase and $0.01 \%$ soybean trypsin inhibitor in HEPES buffer, the composition of which was (in mM) 25 HEPES, $120 \mathrm{NaCl}$, $4 \mathrm{KCl}, 2.6 \mathrm{KH}_{2} \mathrm{PO}_{4}, 2 \mathrm{CaCl}_{2}, 0.6 \mathrm{MgCl}_{2}, 14$ glucose, and $2.1 \%$ $\mathrm{BME}$ amino acid supplement. The tissue squares were gassed with $100 \% \mathrm{O}_{2}$ continuously and kept at $31^{\circ} \mathrm{C}$ for $30 \mathrm{~min}$. The digested tissue was then filtered twice over a polypropylene mesh (pore size $500 \mu \mathrm{M}$ ) and washed in $10 \mathrm{~mL}$ of incubation buffer. The tissue was resuspended in $30 \mathrm{~mL}$ collagenase-free HEPES buffer and triturated to yield dispersed smooth muscle cells. Cells were then collected by gravity filtration over a polypropylene mesh, after which they were centrifuged at 1000 $\times g$ for $5 \mathrm{~min}$, counted, and diluted to a concentration of $2 \times$ $10^{5}$ cells $/ \mathrm{mL}$.

Muscarinic receptor binding assay. The binding of $\left[{ }^{3} \mathrm{H}\right] \mathrm{QNB}$ to muscarinic receptors was measured using previously reported methods (26-28). Briefly, binding of $\left[{ }^{3} \mathrm{H}\right] \mathrm{QNB}$ to circular muscle cells was determined in duplicate samples at a range of concentrations $(0.1-8 \mathrm{nM})$. Each reaction was performed at $31^{\circ} \mathrm{C}$ for $20 \mathrm{~min}$ using $10^{5}$ cells $/ \mathrm{mL}$. After 20 min, the reaction was stopped by the addition of ice-cold HEPES buffer $(0.5 \mathrm{~mL})$, and the cells collected after centrifugation at $14,000 \mathrm{rpm}$ for $10 \mathrm{~min}$. The pellet was washed with $1 \mathrm{~mL}$ of ice-cold incubation buffer and re-spun. The supernatant was pooled into individual scintillation vials. Tissue solubilizer $(0.2 \mathrm{~mL})$ was added to each pellet and incubated for 20 min at $50^{\circ} \mathrm{C}$ or until the pellet dissolved. Each dissolved pellet was transferred into scintillation vials containing glacial acetic acid $(50 \mu \mathrm{L})$ and $8 \mathrm{~mL}$ of scintillation cocktail. After mechanically shaking, all vials were left to adapt and counted in a liquid scintillation counter. Specific $\left[{ }^{3} \mathrm{H}\right] \mathrm{QNB}$ binding was determined by the difference between radioactivity bound in the absence (total binding) and the presence (nonspecific binding) of $1 \mu \mathrm{M}$ atropine. The amount of $\left[{ }^{3} \mathrm{H}\right] \mathrm{QNB}$ bound was determined as the product of the percentage of bound counts per minute (cpm) with the total femtomoles of $\left[{ }^{3} \mathrm{H}\right] \mathrm{QNB}$ in the reaction. Saturation of specific binding sites was examined by increasing the concentration of $\left[{ }^{3} \mathrm{H}\right] \mathrm{QNB}$ from 0.1 to $8 \mathrm{nM}$. Protein estimation was done by the method of Bradford (26), from the sample of cells $\left(10^{5}\right.$ cell $\left./ 0.5 \mathrm{~mL}\right)$. All binding data are then expressed as $\left[{ }^{3} \mathrm{H}\right] \mathrm{QNB}$ bound per milligram protein.

Data analysis. The contractile response was quantified as AUC, using a planimeter. AUC was used as a measure because area is a true measure of a varying signal (tonic and phasic components), such as contractile activity, whereas other measurements are subsets of area measurements (29). The AUC was measured from the beginning of the first contraction after the start of infusion to when the tracing returned to the baseline, and contractions ceased to occur. All data are expressed as a percentage of the maximum response in the normal colon. Values are mean $\pm \mathrm{SEM} ; n$ represents the number of animals. The statistical analysis was done by ANOVA with repeated measures. Multiple comparisons were done by the Fisher protected least squares difference method. A $p$ value $<0.05$ was considered statistically significant.

\section{RESULTS}

Qualitative observations. Under control conditions, animals had good appetite with normal activity and stools. During colitis, they had decreased appetite and activity, abdominal tenderness, and passed bloody, mucoid stools. In controls, the spontaneous activity consisted of periods of quiescence, short and long duration contractions, and colonic migrating motor complexes (MMCs), whereas during colitis, decreased phasic activity, and presence of giant migrating contractions (GMCs) were noted, as described before $(9,14)$. Tissues obtained for in vitro studies were edematous, ulcerated, and laden with mucosal hemorrhages and exudates, and mucosal MPO was significantly increased during colitis.

In vivo effect of muscarine on muscarinic receptors in circular muscle. Whether given during normal and inflamed states, $0.9 \%$ saline infusions did not alter contractile activity either in quiescent or phasic periods. Prior infusions of $75 \mathrm{nmol}$ TTX or $70 \mu \mathrm{mol}$ hexamethonium, which are effective in blocking sodium channel enteric neural conduction and nicotinic receptors, respectively, had no significant effect on the contractile response of circular muscle to muscarine (data not shown, $p=\mathrm{NS}$ ). However, $20 \mathrm{nmol}$ of atropine completely blocked the muscarinic contractile response, thus indicating that muscarine infusions given arterially acted predominantly on muscarinic receptors on smooth muscle cells. Similar findings were noted during inflammation.

Muscarinic response during inflammation. During inflammation, muscarine-mediated, dose-dependent phasic contrac- 
tile responses were attenuated significantly (Table 1; Fig. 1, A and $B$ ). Colitis significantly reduced the phasic contractile response to muscarine at all doses. Supramaximal doses were avoided as the animals in the pilot studies exhibited discomfort and the responses were less than maximal. The significant increase in $\mathrm{EC}_{50}$ doses during inflammation may be reflective of decrease in potency of muscarine in this state (Table 1). In addition, inflamed colon was characteristic for prolonged latency and shortened duration of phasic activity.

Inflammation and muscarinic receptor signaling in vivo. To investigate the role of muscarinic receptor subtypes, the inhibition of the muscarinic control response to increasing doses of pirenzepine, methoctramine, 4-DAMP, tropicamide, and atropine was investigated in normal and inflamed colon (Fig. 2, $A$ and $B$ ). Each inhibitor reduced the muscarinic response in a dose-dependent manner. Under normal conditions, the $\mathrm{IC}_{50}$ of 4-DAMP $\left(\mathrm{M}_{3}\right.$ receptor inhibitor) was 118fold, 22.5-fold, and 146-fold smaller than that of pirenzepine, methoctramine, and tropicamide (Table 2). The $\mathrm{IC}_{50}$ of atropine was similar to that of 4-DAMP. Inflammation did not change the $\mathrm{IC}_{50}$ of 4-DAMP, pirenzepine, tropicamide, or atropine. However, the $\mathrm{IC}_{50}$ of the $\mathrm{M}_{2}$ receptor inhibitor, methoctramine, during inflammation was significantly less than that during the normal state (Table 2).

Comparison of in vivo spontaneous contractile activity with muscarine-activated responses during normal and inflamed states. Spontaneous phasic contractions in the normal state occurred $3.4 \pm 0.3$ times $/ \mathrm{h}$ versus $1.6 \pm 0.3$ times $/ \mathrm{h}$ during inflammation $(p<0.0001 ; n=7 ; d f=6)$. The mean duration of each episode of spontaneous phasic activity lasted significantly longer during the control versus the inflamed state (Table 3). The AUC for phasic and tonic activity were also significantly decreased during inflammation. Similar responses were also noted for muscarine-mediated phasic and tonic contractile activity (Table 3 ). These findings suggest similarities in control of spontaneous and muscarine-activated tonic and phasic contractions, both during the normal and colitis states.

Effect of muscarinic receptor inhibition on spontaneous phasic contractions in vivo. Because mean duration of phasic activity lasted for about 6 min, specific muscarinic receptor inhibitors were infused 2 min after identifying the onset of phasic activity, and suppression of phasic activity was quantified for the next $4 \mathrm{~min}$. The doses of the muscarinic inhibitors were $10 \mathrm{nmol}$ and $200 \mathrm{nmol}$, given arterially, with $0.9 \%$ saline serving as control. At $10 \mathrm{nmol}$ doses, pirenzepine and tropicamide had no impact, but $200 \mathrm{nmol}$ doses resulted in inhibition (Table 4). In contrast, methoctramine inhibited the contractions at both doses. Inasmuch as 10-nmol dose of 4-DAMP totally

Table 1. Characteristics of muscarine-induced contractions in normal and inflamed colon

\begin{tabular}{lrr}
\hline \multicolumn{1}{c}{ Characteristics } & \multicolumn{1}{c}{ Normal } & \multicolumn{1}{c}{ Colitis } \\
\hline $\mathrm{EC}_{50}(\mathrm{nmol})$ & $1.5 \pm 0.5$ & $4.0 \pm 0.7^{*}$ \\
Latency for 5-nmol dose & $16.3 \pm 2.2$ & $28.3 \pm 3.1^{*}$ \\
Duration (min) & $8.1 \pm 1.2$ & $4.7 \pm 0.4^{*}$ \\
AUC $\left(\mathrm{cm}^{2}\right)$ & $21.2 \pm 2.7$ & $10.6 \pm 3.3^{*}$ \\
Maximum response (\%) & $100.0 \pm 0$ & $49.0 \pm 9.6^{*}$ \\
\hline
\end{tabular}

Mean \pm SEM, $n=7, * p<0.05$ vs normal. blocked the contractile activity, much lower doses $0.5 \mathrm{nmol}$ and $2 \mathrm{nmol}$ were used, which significantly attenuated the response. These findings suggest the involvement of $\mathrm{M}_{2}$ and $\mathrm{M}_{3}$ receptors in mediating spontaneous phasic activity in vivo.

Myeloperoxidase activity in vitro. MPO-specific activity was determined in the mucosa-submucosal samples and circular muscle samples from the tissues obtained from normal and inflamed colons ( $n=8$ each). MPO activity per milligram of protein in the mucosa-submucosa during normal state was $0.869 \pm 0.289$, whereas during colitis it was $6.205 \pm 0.881$ (mean $\pm \mathrm{SE}, p<0.001$ ). MPO-specific activity per milligram of protein in circular muscle during normal state was $0.165 \pm$ 0.083 whereas during colitis it was $0.833 \pm 0.281$ (mean $\pm \mathrm{SE}$, $p=\mathrm{NS}, \alpha=0.05, \beta=0.8$ ). The inflammation resulted in a 8 -fold increase in mucosal-submucosal MPO activity, thus suggesting a significant mucosal disease consistently.

Inflammation and muscarinic receptor binding in vitro. In this study, direct measurement of drug binding to receptors using radioligand binding studies involving saturation experiments were done (30). The percentage of specific binding at 0.1 $\mathrm{nM}\left[{ }^{3} \mathrm{H}\right] \mathrm{QNB}$ concentration was $85.1 \pm 2.3$ (normal colon) versus $86.8 \pm 2.3$ (colitis), and percentage of nonspecific binding was $14.9 \pm 2.3 \%$ (normal colon) versus $13.2 \pm 2.3$ (colitis). On the other hand, the percentage of specific binding at $8 \mathrm{nM}\left[{ }^{3} \mathrm{H}\right] \mathrm{QNB}$ concentration was $23.2 \pm 2.0$ (normal colon) versus $17.3 \pm 0.8$ (colitis), and percentage of nonspecific binding was $76.7 \pm 1.9$ (normal colon) versus $95.8 \pm 8.2$ (colitis), respectively. Thus, the sensitivity and specificity of the assays were similar at both the conditions studied.

Specific $\left[{ }^{3} \mathrm{H}\right] \mathrm{QNB}$ binding to muscarinic receptors on isolated circular muscle cells was expressed as bound radioactivity per milligram of protein, and compared between control and inflamed colon. Data were analyzed by nonlinear regression analysis with the help of GraphPad PRISM software. $\mathrm{B}_{\max }$ (receptor density) and $\mathrm{K}_{\mathrm{d}}$ (ligand affinity) were determined and compared between control and inflamed colon. The specific binding of $\left[{ }^{3} \mathrm{H}\right] \mathrm{QNB}$ was saturable at higher concentrations $(r$ $=0.8$ control and $r=0.7$ inflammation, nonlinear regression; Fig. 3). Comparison of variation between the condition (control or inflammation) and concentration (of ligand) was significantly different (ANOVA, $p<0.001$ ). Inflammation produced a significant decrease in $\mathrm{B}_{\max }(4082.2 \pm 281 \mathrm{fmol} / \mathrm{mg}$ control versus $2797.5 \pm 448 \mathrm{fmol} / \mathrm{mg}$ inflammation, $t$ test, $p<0.04$, $d f=8)$. However, $\mathrm{K}_{\mathrm{d}}$ was not different from each other $(0.36$ $\pm 0.06 \mathrm{nM}$ control versus $0.23 \pm 0.06 \mathrm{nM}$ inflammation, $p=$ $0.17, d f=8)$.

\section{DISCUSSION}

The physiologic and pathologic role of cholinergic activation of muscarinic receptors present on the colonic smooth muscle cells in vivo during health or disease is not well known. The novel approach of using segmental arterial infusions facilitated investigation of the in vivo modulation of muscarinic receptor activation of colonic circular muscle cells. Characteristics of spontaneous circular muscle contractions were similar to muscarine-mediated contractions. Similarly, decrease in both spontaneous and muscarine-induced phasic contractile 
A

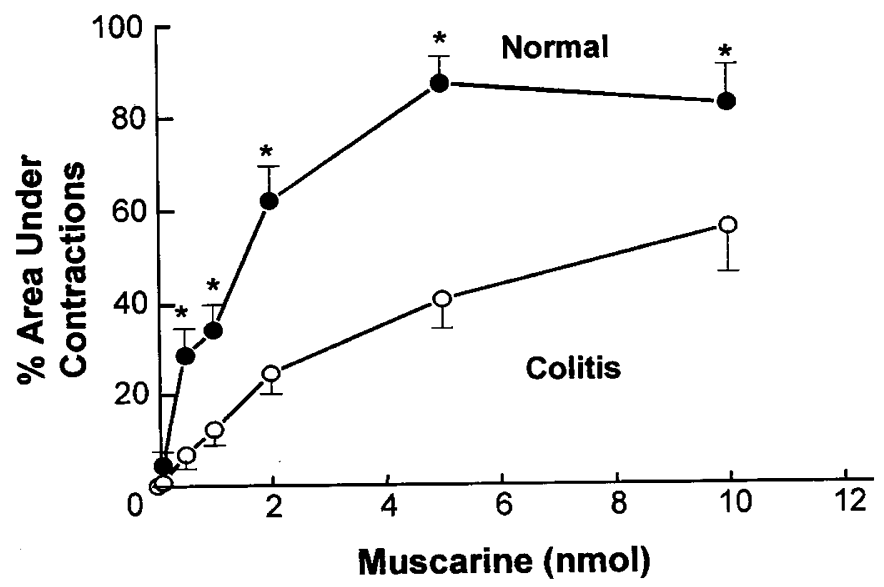

B

NORMAL

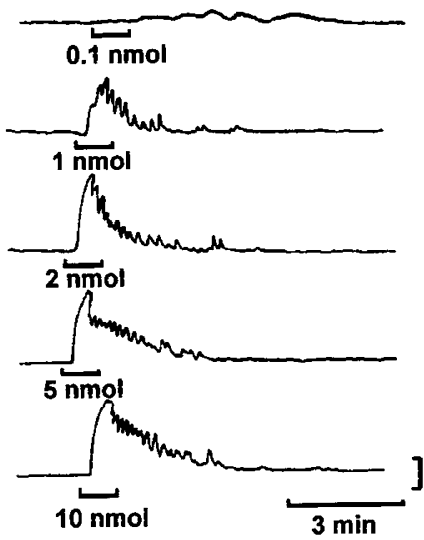

COLITIS

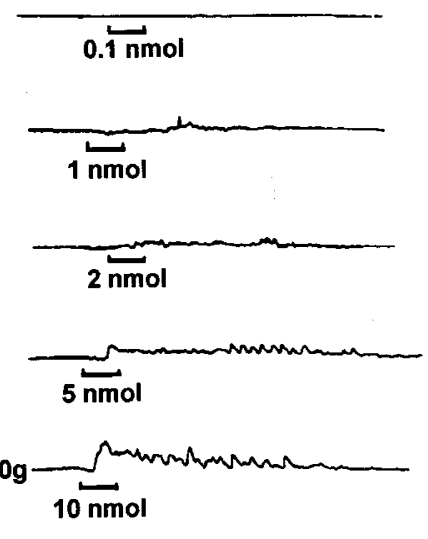

Figure 1. (A) Muscarinic dose response curves from normal (closed circles) and colitis conditions (open circles). The response was significantly decreased both at both lower and higher doses, $n=6, * p<0.05$. $(B)$ A representative tracing of phasic contractile response with graded doses of muscarine infusion in the normal and inflamed colon in the same animal. The responses were decreased during colitis.
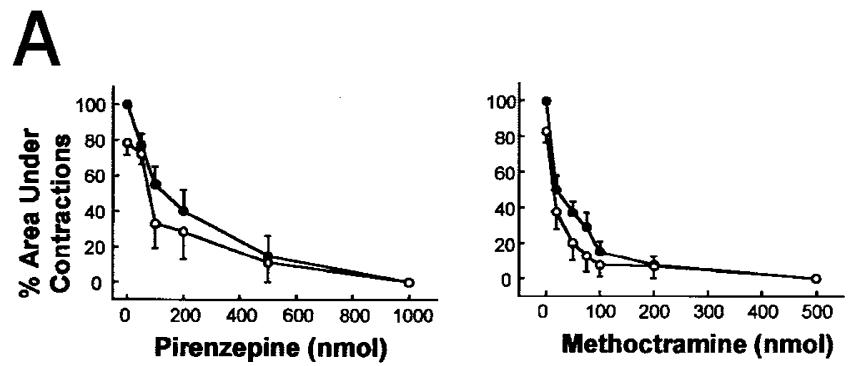

$\mathbf{B}$
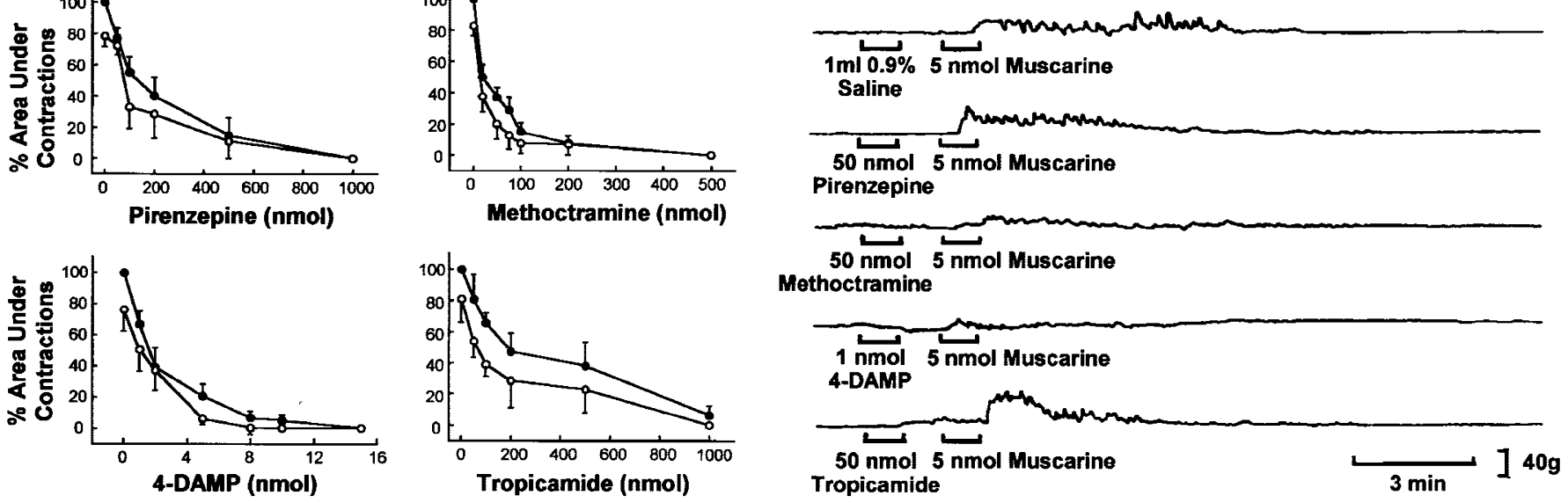

Figure 2. (A) In vivo inhibitory dose response curves to pirenzepine, methoctramine, 4-DAMP, and tropicamide against 5 nmol dose of muscarine during normal (closed circles) and colitis (open circles). The dose-response curve of methoctramine has shifted to the left at lower doses during inflammation. (B) A representative tracing showing the effect of muscarinic antagonists on muscarine-activated contractions in normal colon. Each antagonist was given arterially over $1 \mathrm{~min} ; 1 \mathrm{~min}$ later, muscarine $5 \mathrm{nmol}$ was infused and the response quantified. Note the potency of 4-DAMP in suppressing contractions.

Table 2. $I C_{50}$ (nmol) of muscarinic receptor inhibitors before and during colitis in vivo

\begin{tabular}{lcc}
\hline Muscarinic inhibitors & Before colitis & During colitis \\
\hline Pirenzepine & $236 \pm 100^{*}$ & $156 \pm 104^{*}$ \\
Methoctramine & $45 \pm 12^{*}$ & $15 \pm 3.5^{* \dagger}$ \\
4-DAMP & $2.05 \pm 0.6$ & $1.74 \pm 0.5$ \\
Tropicamide & $291 \pm 99^{*}$ & $174.4 \pm 65.5^{*}$ \\
Atropine & $2.9 \pm 1.2$ & $1.4 \pm 0.7$ \\
\hline
\end{tabular}

Mean \pm SEM; $n=4$ or $5 . * p<0.05$ vs 4-DAMP and atropine; $\dagger p<0.05$ vs before colitis.

activity in all animals was characteristic of colitis, thus suggesting a critical role for cholinergic mediation of phasic activity in normal and colitis states.

Because inhibition of muscarinic receptors by atropine blocked both spontaneous and muscarine-induced contractions, it appears that the final neurotransmitter may still be ACh.
These findings are consistent with those found by others, in that atropine also blocked substance-P mediated contractions to some degree (14). In addition, the decrease in muscarinic response may contribute to the suppression of phasic contractions during colitis. It is possible that during colitis ACh release by myenteric plexus may be decreased as noted in ileitis (12), however exogenous arterial muscarine infusion did not stimulate increased activity during colitis. Thus, these findings suggest the myogenic response is dependent on the muscarinic receptor and postreceptor activation during normal and colitis states.

In this study, muscarinic response was not affected by prior neural or ganglionic blockade using TTX or hexamethonium, respectively, but the same dose of TTX effectively blocked response by EFS. The response to EFS was blocked by atropine also, thus supporting that muscarine infusions given arte- 
Table 3. Characteristics of spontaneous contractile activity vs 5 nmol-muscarine-induced activity before and during colitis

\begin{tabular}{lrrrrr}
\hline & \multicolumn{2}{c}{ Spontaneous contractions } & & \multicolumn{2}{c}{ Muscarine-induced contractions } \\
\cline { 2 - 3 } \cline { 5 - 6 } Characteristics & \multicolumn{1}{c}{ Normal } & Colitis & & Normal & \multicolumn{1}{c}{ Colitis } \\
\hline Duration (min) & $6.1 \pm 0.4$ & $3.5 \pm 0.6^{*}$ & & $8.1 \pm 0.4^{*}$ \\
AUC (phasic, $\left.\mathrm{cm}^{2}\right)$ & $13.3 \pm 2.5$ & $4.1 \pm 1.6^{*}$ & & $21.2 \pm 2.7$ & $10.6 \pm 3.3^{*}$ \\
AUC (tonic, $\mathrm{cm}^{2}$ ) & $7.6 \pm 1.5$ & $3.0 \pm 1.0^{*}$ & & $12.3 \pm 2.0$ & $6.7 \pm 3.2^{*}$ \\
\hline
\end{tabular}

Mean $\pm \mathrm{SEM} ; n=7$. $* p<0.05$ vs normal.

Table 4. Inhibition of spontaneous phasic contractile activity of circular muscle by muscarinic inhibitors

Percentage of AUC after each inhibitor with $0.9 \%$ saline as $100 \%$ response

\begin{tabular}{lrrrr}
\cline { 2 - 4 } Dose & Pirenzapine & Methoctramine & 4-DAMP & Tropicamide \\
\hline $0.5 \mathrm{nmol}$ & & $58.4 \pm 31^{*}$ \\
$2.0 \mathrm{nmol}$ & & $33.2 \pm 18^{*}$ & \\
$10 \mathrm{nmol}$ & $101.4 \pm 10$ & $59 \pm 12^{*}$ & & $76 \pm 28$ \\
$200 \mathrm{nmol}$ & $54 \pm 11^{*}$ & $31.1 \pm 11^{*}$ & & $56 \pm 12^{*}$ \\
\hline
\end{tabular}

Mean $\pm \mathrm{SEM} ; n=5 . * p<0.05$ vs control.

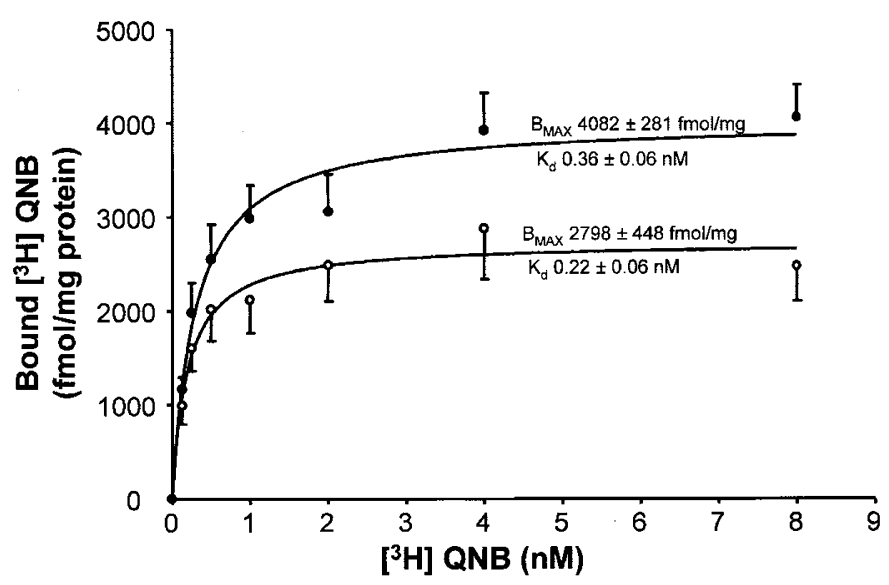

Figure 3. Specific binding of $\left[{ }^{3} \mathrm{H}\right] \mathrm{QNB}$ to isolated SMC from the normal ( $n$ $=6$, closed circles $)$ and inflamed colon $(n=4$, open circles $) . \mathrm{B}_{\max }$ decreased significantly during inflammation $(p<0.05)$, whereas $\mathrm{K}_{\mathrm{d}}$ did not.

rially activate primarily the muscarinic receptors on the smooth muscle cells, and not activate the muscarinic receptors on the postsynaptic neurons or enteric ganglia.

The contractility of circular muscle to muscarine was dosedependent, suggesting an increasing recruitment of muscarinic receptors or postreceptor signal transduction mechanisms in mediating this response. This trend was also seen during colitis but the contractility was significantly decreased at both lower and higher doses of muscarinic agonists. It is possible that this change in response during inflammation may be due to a change in receptor affinity or density. The radioligand binding studies showed a decrease in $\mathrm{B}_{\max }$ during inflammation, thus suggesting a decrease in receptor density. On the contrary, there was no change in $K_{d}$ or receptor affinity. Based on the saturation experiments, we infer that the receptor density is decreased during inflammation; the nature of this decrease may be related to down-regulation of mRNA synthesis of the muscarinic receptors, or other signal transduction pathways (30-33).

Lu et al. (31) found that colitis altered specific parameters of slow waves in colon and reduced the amplitude of spontaneous spike-independent in vitro phasic contractions, and that this may be related to alteration in interstitial cells of Cajal function. The similarity between in vivo and in vitro contractility indicates that the reduced muscarinic response during inflammation was not due to changes in blood flow or mucosal transport, inasmuch as the muscle strips were devoid of mucosa and blood flow. Alternatively, the decrease in contractility during inflammation may be modulated due to specific muscarinic receptor subtype-mediated postreceptor modification mechanisms, such as intracellular signaling pathways mediated by G-protein activation, intracellular $\mathrm{Ca}^{2+}$ release, protein kinase $\mathrm{C}$ activation, $\mathrm{IP}_{3}$ activation, and release and phosphorylation of myosin light chain kinases $(32,33)$.

A significant inhibitory response of a small dose $(0.5 \mathrm{nmol})$ of $\mathrm{M}_{3}$ receptor antagonist in decreasing in vivo spontaneous contractile activity is suggestive of greater potency of $\mathrm{M}_{3}$ receptor subtype in mediating circular muscle contraction. In contrast, methoctramine, pirenzepine, and tropicamide were able to suppress contractions to the same magnitude at a dose 20-fold, 400-fold, and 400-fold higher than 4-DAMP, respectively. Because all currently available muscarinic receptor subtype inhibitors are only relatively specific, the decreased contractile effects at higher doses of these $\mathrm{M}_{1}$ and $\mathrm{M}_{4}$ antagonists may be due to a nonspecific inhibitory effect mediated at more than one muscarinic receptor subtypes. From this data, we may conclude that spontaneous phasic circular muscle contractions are mediated primarily by $\mathrm{M}_{3}$ receptors, and to some extent by $\mathrm{M}_{2}$ receptors. Similar findings were found consistent with muscarinic agonist-mediated contractions in that $\mathrm{M}_{3}$ receptor sub-type inhibitor suppressed muscarinic agonist-mediated circular muscle contractions more than that of others, as evidenced by the fact that $\mathrm{IC}_{50}$ of $\mathrm{M}_{3}$ antagonist was 22.5-fold lesser than $\mathrm{M}_{2^{-}}, 118$-fold lesser than $\mathrm{M}_{1^{-}}$, and 145-fold lesser than $\mathrm{M}_{4}$-antagonists.

Muscarinic receptors transduce ACh signals by activating $\mathrm{G}$ proteins to regulate the generation of second messengers (3436). From our studies, during inflammation there was no significant change in the inhibitory effects of $\mathrm{M}_{1}, \mathrm{M}_{3}$, and $\mathrm{M}_{4}$ antagonists or atropine, but the $\mathrm{IC}_{50}$ dose of $\mathrm{M}_{2}$ antagonist decreased significantly during inflammation. The signal transduction mechanisms for the activation of $\mathrm{M}_{2}$ and $\mathrm{M}_{3}$ receptors are different $(36,37) . M_{3}$ receptors activate $G_{q}$-protein that induces phosphinositide hydrolysis to synthesize $\mathrm{IP}_{3}$ and DAG. $\mathrm{M}_{2}$ receptors activate $\mathrm{G}_{\mathrm{i}}$-protein that inhibits the activation of adenylyl cyclase and, hence the synthesis of cAMP. $\mathrm{IP}_{3}$ synthesis increases cytosolic $\mathrm{Ca}^{2+}$ by intracellular $\mathrm{Ca}^{2+}$ release, whereas cAMP inhibits $\mathrm{IP}_{3}$ synthesis, $\mathrm{IP}_{3}$-induced $\mathrm{Ca}^{2+}$ influx and stimulates $\mathrm{Ca}^{2+}$ uptake in intracellular stores (37). Thus, $\mathrm{M}_{3}$ receptor activation stimulates contractions directly, 
whereas $\mathrm{M}_{2}$ receptor activation stimulates them indirectly by inhibiting an inhibitory effect. The significant decrease in the $\mathrm{IC}_{50}$ dose of $\mathrm{M}_{2}$ receptor antagonist (22.5-fold to 9-fold over 4-DAMP) during colitis suggests that the $\mathrm{M}_{2}$ receptor stimulation may partly contribute to the phasic activity by inhibiting adenylyl cyclase. Thus, colonic circular muscle contractility may be mediated by primarily $M_{3}$ receptors and possibly $M_{2}$ receptors. Similar results were noted in cat esophageal and lower esophageal sphincter circular muscle cells in that $\mathrm{M}_{2}$ and $\mathrm{M}_{3}$ muscarinic receptors evoke different responses $(25,37)$.

The changes noted in muscarinic receptor signaling mechanisms in the circular smooth muscle in this study during colitis in our model may have been mediated by any of the inflammatory mediators studied in other animal studies. These include 1) marked increase in mucosal permeability and possible translocation of inflammatory mediators or infective organisms $(9,38)$; 2) neutrophil influx, MPO activity, and generation of superoxide radicals $(39,40) ; 3)$ increased production of arachidonic metabolites, immunoreactive 6-ketoprostaglandin $1 \alpha$, leukotriene $\mathrm{B}_{4}$, or thromboxane $\mathrm{B}_{2}(18,19,41)$. Although $\mathrm{ACh}$ may be the chief neurotransmitter in the enteric nervous system, it is also likely that other putative neurotransmitters may also be affected during inflammation such as tachykinins, as seen in colitis in canine or in humans $(14,42)$.

In conclusion, inflammation suppresses the tonic and phasic contractile response to spontaneous and muscarinic receptor activation of circular smooth muscle in vivo. The primary mediator of spontaneous phasic contractions in circular muscle appears to be $M_{3}$ receptor subtype, however inflammation modulates the $\mathrm{M}_{2}$ receptor function as indicated by significant increase in the potency of methoctramine. The decrease in phasic activity during inflammation may be due to alteration of density of muscarinic receptors or changes in postreceptor changes in signaling. The cholinergic mechanisms shown in this study may contribute to the abnormal motility seen with inflammatory bowel disease.

Acknowledgments. The author thanks Stephen J. Elliott, M.D., and Sushil K. Sarna, Ph.D., for the critical advice during this study, Ron Hines, Ph.D., for reviewing the manuscript, and Bob Ryan and Valerie Wujcik for technical support.

\section{REFERENCES}

1. Lee KY, Park HJ, Chang TM, Chey WY 1983 Cholinergic role on release and action of motilin. Peptides 4:375-380

2. Ormsbee III HS, Telford GL, Mason GR 1979 Required neural involvement in control of canine migrating motor complex. Am J Physiol 237:E451-E456

3. Sarna SK, Stoddard C, Belbeck L, McWade D 1981 Intrinsic neural control of migrating myoelectric complexes. Am J Physiol 241:G16-G23

4. Szurszewski JH 1987 Electrophysiological basis for gastrointestinal motility. In: Johnson LR (ed) Physiology of the Gastrointestinal Tract, Vol I. Raven, New York, pp 383-422

5. Goyal RK 1989 Muscarinic receptor subtypes: physiology and clinical implications. N Engl J Med 321:1022-1029

6. Kern FJ, Almy TO, Abbot FK, Bogdonoff MD 1951 The motility of the distal colon in nonspecific ulcerative colitis. Gastroenterology 19:492-503

7. Spriggs EA, Code CF, Bargen JA, Curtiss RK, Hightower Jr NC 1951 Motility of the pelvic colon and rectum of normal persons and patients with ulcerative colitis. Gastroenterology 19:480-491

8. Sarna SK 1989 In vivo myoelectric activity: methods, analysis and interpretation. In: Wood JD (ed) Handbook of Physiology, Gastrointestinal Motility and Circulation. American Physiological Society, Bethesda, MD, pp 817-863

9. Sethi AK, Sarna SK 1991 Colonic motor activity in acute colitis in conscious dogs. Gastroenterology 100:954-963
10. Jadcherla SR, Sarna SK 1996 Inflammation modulates the colonic contractile response to muscarinic receptor activation. Dig Dis Sci 41:A71

11. Otterson MF, Sarna SK 1989 Enteric neural control of giant migrating contractions. J Gastrointest Motil 1:50-56

12. Collins SM, Blennerhassett PA, Blennerhassett MG, Vermillion DL 1989 Impaired acetylcholine release from the myenteric plexus of Trichenella-infected rats. Am J Physiol 257:G898-G903

13. Zhang Z, Koch TR, Mustin E, Walgenbach-Telford S, Telford GL 1993 Muscarinic cholinergic receptor density following small intestinal transplantation in rats. Am J Physiol 265:G1057-G1063

14. Tsukamoto M, Sarna SK, Condon RE 1997 A novel motility effect of tachykinins in normal and inflamed colon. Am J Physiol 272:G1607-G1614

15. Choo LK, Mitchelson FJ 1985 Comparison of the affinity constant of some muscarinic receptor antagonists with their displacement of $[3 \mathrm{H}]$ quinuclidinyl benzilate binding in atrial and ileal longitudinal muscle of the guinea-pig. J Pharm Pharmacol 37:656658

16. Birdsall NJ 1989 Receptor structure: the accelerating impact of molecular biology. Trends Pharmacol Sci 10:50-52.

17. Lazareno S, Birdsall NJM 1993 Pharmacological characterization of acetylcholinestimulated $\left[{ }^{35} \mathrm{~S}\right]-\mathrm{GTP} \gamma \mathrm{S}$ binding mediated by human muscarinic $\mathrm{m} 1-\mathrm{m} 4$ receptors; antagonist studies. Br J Pharmacol 109:1120-1127

18. Sharon P, Stenson WF 1985 Metabolism of arachidonic acid in acetic acid colitis in rats. Gastroenteology 88:55-63

19. Sharon P, Stenson WF 1984 Enhanced synthesis of leukotriene B by colonid mucosa in inflammatory bowel disease. Gastroenterology 86:453-460

20. Castro GA, Roy SA, Stockstill RD 1974 Trichinella spiralis: peroxidase activity in isolated cells from the rat intestine. Exp Parasitol 36:307-315

21. Maehly AC, Chance B 1954 The assay of catalases and peroxidases. In: D. Glick (ed) Methods of Biochemical Analysis. Interscience Publishers, New York, pp 357-408

22. Bradford, MM 1976 A rapid and sensitive method for the quantitation of microgram quantities of protein utilizing the principle of protein-dye binding. Annal Biochem $72: 248-254$

23. Shi XZ, Sarna SK 1997 Inflammatory modulation of muscarinic receptor activation in canine ileal circular muscle cells. Gastroenterology 112:864-874

24. Shi XZ, Sarna SK 2000 Impairment of $\mathrm{Ca}^{2+}$ mobilization in circular muscle cells of the inflamed colon. Am J Physiol Gastrointest Liver Physiol 278:G234-G242

25. Dong Sohn UY, Harnett KM, De Petris G, Behar J, Biancani P 1993 Distinct muscarinic receptors, $\mathrm{G}$ proteins and phospholipases in esophageal and lower esophageal sphincter circular muscle. J Pharmacol Exp Ther 267:1205-1214

26. Chin BC, Tan DTM, Brent Scott R 1996 Depressed smooth muscle contractility after massive intestinal resection in rat. Can J Physiol Pharmacol 74:1187-1195

27. Cuq P, Magous R, Bali JP 1994 Pharmacological coupling and functional role for the muscarinic receptor subtypes in isolated cells from the circular smooth muscle of the rabbit cecum. J Pharmacol Exp Ther 271:149-155

28. Cuq P, Magous R, Bali JP 1994 Signal transduction pathways of muscarinic receptors in circular smooth muscle from the rabbit cecum. Mol Cell Biochem 140:65-71

29. Reddy SN, Bazzocchi G, Chan S, Akashi K, Villanueva-Meyer J, Yanni G, Mena I, Snape Jr WJ 1991 Colonic motility and transit in health and ulcerative colitis. Gastroenterology 101:1289-1297

30. Haylett DG 1996 Direct measurement of drug binding to receptors. In: Foreman JC, Johansen T (eds) Textbook of Receptor Pharmacology. CRC Press, Boca Raton, FL, pp 121-149

31. Lu G, Qian X, Berezin I, Telford GL, Huizinga JD, Sarna SK 1997 Inflammation modulates in vitro colonic myoelectric and contractile activity and interstitial cells of cajal. Am J Physiol 273:G1233-G1245

32. Zhang L, Buxton ILO 1991 Muscarinic receptors in canine colonic circular smooth muscle. II. Signal transduction pathways. Mol Pharmacol 40:952-959

33. Zhang L, Horowitz B, Buxton ILO 1991 Muscarinic receptors in canine colonic circular smooth muscle. I. Coexistence of M2 and M3 subtypes. Mol Pharmacol 40:943-951

34. Lepor H, Mohler J, Baumann M, Shapiro E 1989 Comparison of muscarinic cholinergic and alpha-adrenergic receptors in canine ileum, colon, intestinal urinary reservoirs and bladder. J Urol 142:204-207

35. Carrier GO, Aronstam RS 1990 Increased muscarinic responsiveness and decreased muscarinic receptor content in ileal smooth muscle in diabetes. J Pharmacol Exp Ther 254:445-449

36. Takahashi T, Kurosawa S, Owyang C 1994 Regulation of PI hydrolysis and cAMP formation by muscarinic $\mathrm{M}_{3}$ receptor in guinea pig gallbladder. Am J Physiol 267:G523-G528

37. Murthy KS, Makhlouf GM 1997 Differential coupling of muscarinic $M_{2}$ and $M_{3}$ receptors to adenylyl cyclases V/VI in smooth muscle. J Biol Chem 272:2131721324

38. Conner EM, Grisham MB 1996 Animal models of colitis. In: Gaginella TS (ed) Experimental Models of Mucosal Inflammation. CRC Press, Boca Raton, FL, pp 97-109

39. Yamada T, Marshall S, Specian RD, Grisham MB 1992 A comparative analysis of two models of colitis in rats. Gastroenterology 102:1524-1534

40. Seikizuka E, Grisham MB, Li M, Deitch EA, Granger DN 1988 Inflammation induced intestinal hyperemia in the rat: role of neutrophils. Gastroenterology 95:1528-1534

41. Vilaseca J, Salas A, Guarner F, Rodriguez R, Malagelada J-R 1990 Participation of thromboxane and other eicosanoid synthesis in the course of experimental inflammatory colitis. Gastroenterology 98:269-277

42. Al-Saffar, Hellstrom PM 2001 Contractile responses to natural tachykinins and selective tachykinin analogs in normal and inflamed ileal and colonic muscle. Scand J Gastroenterol 36:485-493 